\title{
PENGARUH KARAKTERISTIK MULTINASIONALITAS DAN THIN CAPITALIZATION TERHADAP EFFECTIVE TAX RATE
}

\author{
Hari Hananto
}

\author{
Fakultas Bisnis dan Ekonomika, Universitas Surabaya, Surabaya, Indonesia
}

DOI: $\underline{\text { https://doi.org/10.24123/jati.v14i2.4869 }}$

\begin{abstract}
The company always tries to minimize tax payments through various ways. In particular, a multinational company has more ability to do tax avoidance. One technique that can be used by multinational corporations is to transfer corporate income from one jurisdiction to another that has a lower corporate income tax rate to minimize overall group tax payments. This mechanism can result in superior tax payments for multinational companies that have subsidiaries or affiliated companies. In addition to income transfer, multinational companies can also regulate their capital composition in order to take advantage of the ease of obtaining capital in a jurisdiction.

This study aims to show empirical evidence about the effect of the nature of multinationality (multinational companies) and the existence of capitalization (thin capitalization) on the possibility of tax avoidance. The population sample used in this study were companies listed on the IDX during the 2017-2019 period. The results show that multinational companies have an effect on increasing tax avoidance efforts. Meanwhile, thin capitalization has no effect on efforts to increase tax avoidance.
\end{abstract}

Keywords: Multinational Companies; Tax Avoidance; Thin Capitalization.

\begin{abstract}
Abstrak:
Perusahaan senantiasa berusaha meminimalkan pembayaran pajak melalui berbagai macam cara. Secara khusus, sebuah perusahaan multinasional, memiliki kemampuan lebih dalam melakukan penghindaran pajak. Salah satu teknik yang dapat digunakan oleh perusahaan multinasional adalah memindahkan penghasilan perusahaan pada sebuah yurisdiksi dipindah ke yurisdiksi lain yang memiliki tingkat pajak penghasilan badan yang lebih rendah untuk meminimalkan pembayaran pajak grup secara keseluruhan. Mekanisme ini dapat menghasilkan keunggulan pembayaran pajak pada perusahaan multinasional yang memiliki anak perusahaan maupun perusahaan afiliasi. Disamping pemindahan penghasilan, perusahaan multinasional juga bisa mengatur komposisi modalnya guna memanfaatkan kemudahan-kemudahan perolehan modal di sebuah yurisdiksi.

Penelitian ini bertujuan untuk menunjukkan bukti empiris tentang pengaruh sifat multinasionalitas (perusahaan multinasional) dan adanya pengaturan modal (thin capitalization) terhadap kemungkinan melakukan penghindaran pajak. Sampel populasi yang digunakan pada penelitian ini adalah perusahaan terdaftar di BEI selama periode 2017-2019. Hasil penelitian menunjukkan bahwa bahwa perusahaan multinasional memiliki pengaruh dalam meningkatkan upaya penghindaran pajak. Sementara itu thin capitalization tidak berpengaruh pada usaha-usaha peningkatan penghindaran pajak.
\end{abstract}

Kata kunci: Penghindaran Pajak, Perusahaan Multinasional, Thin Capitalization

*Korespondensi : hananto@ staff.ubaya.ac.id 


\section{PENDAHULUAN}

Globalisasi menyebabkan perusahaan dapat bebas beroperasi dan memperluas pasar tanpa terbatasi oleh wilayah suatu negara (Wolf, 2004). Perusahaan-perusahaan multinasional/multinational corporation (MNC) dapat beroperasi di lebih dari satu negara. Kondisi ini juga berdampak pada sisi perpajakan di negara-negara tempat mereka beroperasi. MNC memiliki keunggulan kompetitif yang tidak dimiliki oleh perusahaan domestik (Aggarwal \& Kyaw, 2008), MNC memiliki keunggulan dalam memanfaatkan praktik profit shifting dalam usaha untuk efiensi pembayaran pajak (Kemenkeu Learning Center, 2020) Berbagai penelitian dilakukan untuk melihat pengaruh praktik profit shifting yang dilakukan oleh perusahaan multinasional.

Cristea dan Nguyen (2016) menemukan bahwa terdapat praktik transfer pricing dalam perusahaan multinasional asal negara Denmark melalui pengaturan harga transfer saat mengekspor produk ke perusahaan afiliasi di negara lain yang memiliki tingkat pajak lebih rendah daripada di negara Denmark. Penerapan harga transfer atas ekspor produk melaporkan laba dari penjualan ekspor yang lebih rendah sehingga pajak terutang akan lebih rendah. Sebagai akibatnya Denmark, sebagai tax base, kehilangan sekitar \$141 juta pendapatan ekspornya. Pemindahan laba dari yurisdiksi suatu negara dengan tingkat pajak yang lebih tinggi ke yurisdiksi lain dengan tingkat pajak yang lebih rendah, yang menyebabkan berkurangnya tax base di negara dengan tingkat pajak lebih tinggi dan tentunya menurunkan penerimaan pajak korporat di negara-negara yang terdampak (OECD, 2017). Domestic tax base erosion and profit shifting (BEPS) adalah sebuah isu internasional yang merugikan banyak negara, yang merugikan pemerintah di seluruh dunia dari sisi pajak sekitar \$100-240 miliar setiap tahunnya. Profit shifting berkaitan erat dengan negara tax haven, yaitu negara-negara dengan tarif pajak korporat (atau individu) asing efektif yang rendah (Financial Times Lexicon, 2015). Perusahaan multinasional asal Amerika Serikat pada tahun 2011 melaporkan 42,6\% laba dari operasi di luar negeri dalam yurisdiksi negara-negara tax haven (Dharmapala, 2014) Dampaknya adalah berkurangnya pendapatan pajak korporat Amerika Serikat antara \$77-111 miliar pada tahun 2012, berdasarkan data survei dari Bureau of Economic Analysis yang didapatkan dari periode 1983-2012 (Clausing, 2015).

Pemerintah Indonesia juga mengalami dampak dari praktik profit shifting yang dilakukan oleh PT Adaro Energy Tbk (ADRO), yang menggunakan perusahaan anak di Singapura untuk memindahkan labanya dengan penetapan transfer pricing yang agresif (Sugianto, 2019). PT Bentoel Internasional Investama Tbk (RMBA) yang merupakan 
perusahaan anak dari British American Tobacco (BAT) menggunakan sarana pinjaman intraperusahaan dengan perusahaan afiliasi yang terdaftar di Belanda, Rothman Far East BV mampu mengurangi penghasilan kena pajak. Sebagai akibatnya, Indonesia kehilangan sebesar \$14 juta pendapatan pajak setiap tahunnya (Tax Justice Network, 2019; Ortax, 2019). Tim Transparansi Industri Ekstraktif menemukan bahwa puluhan perusahaan tambang mineral dan batubara yang beroperasi di Indonesia tidak menyerahkan data produksi dan setoran pajak (Tim Transparansi Industri Ekstraktif, 2012; Tempo, 2012). Permasalahan profit shifting direspon organisasi multinasional OECD dan G20 dengan mengembangkan OECD G20 Base Erosion and Profit Shifting Project. Organisasi ini merupakan kerjasama antara 135 negara dan yurisdiksi untuk mengimplementasikan 15 strategi guna mengurangi tax avoidance dengan cara memitigasi celah pada peraturan perpajakan antar negara.

Klassen \& Laplante (2012) juga menemukan bahwa perusahaan multinasional dapat mendirikan struktur perusahaan dengan thin capitalization untuk mendapatkan insentif perpajakan sehingga usaha pemerintah maksimalisasi pendapatan pajak tidak tercapai. Thin capitalization menunjukkan bahwa perusahaan lebih banyak menggunakan utang dalam membiayai operasional perusahaannya. Penggunaan utang yang besar ini berdampak pada munculnya beban bunga yang besar pula (finance cost). Debt financing melalui perusahaan afiliasi menyebabkan taxable income yang rendah akibat pembayaran bunga pinjaman yang deductible.

Penelitian oleh Readhead (2016) tentang public finance policy di negara berkembang menemukan bahwa perusahaan multinasional membayar lebih sedikit pajak dari semestinya karena periode konsesi pajak yang panjang, praktik transfer pricing, insentif investasi, dan perlindungan tarif dari pemerintah setempat. Penelitian Suqih dan Jasman (2018) tentang determinan profit shifting, menyimpulkan faktor multinasionalitas, agresivitas transfer pricing, dan aset tak berwujud memiliki korelasi positif yang signifikan terhadap penggunaan tax haven (menunjukkan upaya penghindaran pajak) sedangkan thin capitalization dan ukuran perusahaan tidak berpengaruh terhadap penggunaan tax haven. Dengan kata lain, perusahaan berkarakteristik multinasional tidak terbukti melakukan usaha-usaha penghindaran pajak. Namun, penelitian yang dilakukan oleh Twesige dan Gasheja (2019) terhadap multinasional yang beroperasi di Rwanda menyatakan hasil yang berbeda, dimana terdapat pengaruh negatif antara finance cost dan taxable income. Hal tersebut menunjukkan bahwa karakteristik multinasional berpengaruh negatif terhadap pendapatan pajak yang berarti terjadi peningkatan penghindaran pajak 
Adanya research gap antara hasil temuan-temuan penelitian tersebut membuat perlu untuk menelaah kembali pengaruh karakteristik perusahaan multinasional terhadap penghindaran pajak. Data penelitian menggunakan perusahaan yang terdaftar di BEI selama periode 2017-2019 dari seluruh sektor industri kecuali sektor jasa finansial dan jasa asuransi.

\section{TELAAH TEORETIS}

\section{Tax Avoidance}

Menurut Pohan (2016), tax avoidance adalah upaya penghindaran pajak untuk memperkecil jumlah pajak yang terutang yang dilakukan sesuai regulasi perpajakan sehingga secara teknis legal untuk dilakukan bagi wajib pajak. Tax avoidance menggunakan berbagai metode dan teknik yang memanfaatkan celah dan kelemahan (grey area) dalam undang-undang dan peraturan perpajakan. (Pohan, 2016). Kerumitan permasalahan tax avoidance terletak pada sifatnya sebagai tindakan yang merugikan pendapatan negara namun bukan merupakan praktik yang melanggar ketentuan hukum (Maharani dan Suardana, 2014).

\section{Multinational Corporations (MNC)}

Root (1994) mendefinisikan MNC sebagai perusahaan yang: i) memiliki kapasitas produksi barang dan/atau jasa melalui perusahaan afiliasi yang terletak di negara-negara lain di luar negara asal MNC; ii) memiliki kendali atas pengambilan keputusan di perusahaan afiliasi di luar negeri; iii) mengimplementasi strategi bisnis transnasional dalam proses produksi, pemasaran, keuangan, dan pengorganisasian yang terletak di lebih dari satu negara. Selain itu, salah satu kriteria MNC adalah struktur kepemilikan dimana pusat badan usaha secara efektif dimiliki oleh anggota warga lebih dari satu negara, seperti Shell dan Unilever yang berada dalam kendali warga negara Inggris dan Belanda (Root, 1973).

Perusahaan multinasional menjalankan dan memiliki operasional bisnis yang tersebar di berbagai negara. Perusahaan multinasional melakukan ekspansi ke negara-negara lain dengan harapan untuk meningkatkan performa melalui scale economies, akses terhadap teknologi, dan perbedaan biaya operasi (Porter, 1985) Kontrol perusahaan multinasional terhadap perusahaan afiliasinya di negara-negara lain memunculkan keuntungan tersendiri sehingga mampu dimanfaatkan untuk memperoleh keuntungan pembayaran pajak. Pengurangan pembayaran pajak dilakukan dengan memanfaatkan celah peraturan perpajakan antar-negara. Perusahaan yang menjalankan operasi bisnis di lebih banyak negara dapat dikatakan sebagai lebih multinasional dan semakin mempunyai banyak kesempatan dalam memperoleh keuntungan pembayaran pajak. 
Tax treaty atau Perjanjian Penghindaran Pajak Berganda (P3B) adalah upaya antar negara guna menghindari pengenaan pajak berganda. Perjanjian ini menghasilkan berbagai kesepakatan yang saling menguntungkan dalam hal perpajakan. P3B antara yurisdiksi dapat dimanfaatkan untuk tax avoidance oleh perusahaan multinasional melalui praktik treaty shopping yaitu pemilihan yurisdiksi sehingga tingkat pajak korporat yang dihasilkan menjadi menguntungkan untuk penghematan beban pajak yang ditanggung oleh grup perusahaan secara keseluruhan dapat diminimalkan (Yonah dan Panayi, 2010).

Penyalahgunaan P3B juga dapat dilakukan dengan cara menggunakan pasal-pasal dalam P3B yang tidak sesuai dengan tujuan tax treaty. Salah satu contoh dari praktek ini adalah mengeksploitasi perjanjian double-tax treaty sehingga perusahaan multinasional tidak membayarkan pajak di negara asal dan negara perusahaan afiliasinya. Hal ini menyebabkan double non-taxation di kedua negara tempat operasi perusahaan dan tempat sumber pendapatan tidak dapat memungut pajak dari perusahaan tersebut. Perencanaan pajak secara agresif (penghindaran pajak) oleh perusahaan multinasional dilakukan dengan memanfaatkan celah peraturan perpajakan antar-negara untuk mengurangi beban pajak yang harus dibayarkan (The European Commission, 2012). Penelitian oleh Taylor et.al (2015) menunjukkan hubungan yang signifikan antara multinasionalitas perusahaan dengan effective tax rate (tingkat penghindaran pajak) Praktek profit shifting oleh perusahaan-perusahaan multinasional asal Amerika Serikat telah didokumentasikan dalam studi oleh Klassen \& Laplante (2012) dan Dyreng \& Lyndsey (2009).

Effective tax rate (ETR) perusahaan multinasional Amerika Serikat secara global mencapai $1,5 \%$ lebih rendah dibandingkan dengan perusahaan yang tidak memiliki akses terhadap sarana profit shifting melalui negara tax haven. Tax haven adalah berbagai yurisdiksi yang menetapkan tingkat pajak penghasilan rendah atau bahkan tidak menetapkan pajak penghasilan (Wilson, 2009). Hal ini menjadikan yurisdiksi tax haven menarik bagi perusahaan multinasional untuk penghematan beban pajak dengan mendirikan kantor representasi di yurisdiksi tersebut dengan tujuan melakukan skema pengalihan penghasilan melalui manipulasi harga transfer dan pengubahan struktur keuangan perusahaan pada yurisdiksi dengan tingkat pajak tinggi untuk meningkatkan nilai pembayaran beban keuangan yang merupakan deductible expense untuk mengurangi pajak terutang (Gruber dan Mutti, 1991). Penggunaan tax haven dalam praktik profit shifting adalah sebuah isu yang mendapatkan perhatian serius oleh OECD, G-20, dan berbagai otoritas pajak di dunia terkait isu tax avoidance (Gravelle, 2013). 
Profit shifting adalah strategi tax avoidance yang digunakan oleh perusahaan multinasional untuk memindahkan penghasilan yang dapat dikenakan pajak dari suatu negara ke negara lain yang memiliki tingkat pajak lebih rendah (PWC, 2011). Profit shifting dapat dilakukan melalui manipulasi transfer pricing dengan cara menetapkan harga transfer serendah-rendahnya untuk barang ke perusahaan afiliasi di negara dengan tingkat pajak tinggi dan sebaliknya menetapkan harga transfer setinggi-tingginya untuk barang dari perusahaan afiliasi di negara tax haven. Tujuannya adalah untuk memaksimalkan penghasilan perusahaan afiliasi yang terletak di negara tax haven dan meminimalkan penghasilan kena pajak di perusahaan afiliasi yang terdampak tingkat pajak yang lebih tinggi.

Praktik profit shifting menyebabkan fenomena base erosion, yaitu berkurangnya sumber pajak penghasilan (tax-base) dari negara-negara dengan tingkat pajak penghasilan korporat yang lebih tinggi (OECD, 2010). Pada tahun 2017 OECD memperkirakan munculnya kerugian pendapatan pajak negara-negara di dunia akibat penggunaan sarana BEPS oleh perusahaan multinasional mencapai USD 100-240 miliar. Negara berkembang bahkan diestimasi kehilangan USD 500 miliar per tahun akibat praktik BEPS (Tax Justice Network, 2017).

Perusahaan Amerika Serikat yang melakukan profit shifting, lebih unggul dalam melaksanakan praktik tax avoidance dibandingkan dengan perusahaan domestik yang tidak dapat melakukan profit shifting (Rego, 2003). Penelitian oleh Hanlon, Mills, dan Slemrod (2005) juga menemukan bahwa tingkat ketidakpatuhan perpajakan oleh perusahaan afiliasi multinasional di Amerika Serikat mencapai lebih dari dua kalinya perusahaan domestik. Berdasarkan literatur yang tersedia, penelitian ini mengembangkan hipotesis berikut:

H1: sifat multinationality perusahaan berpengaruh positif terhadap penghindaran pajak.

\section{Thin Capitalization}

Thin capitalization adalah keadaan sebuah perusahaan dimana tingkat hutangnya lebih besar daripada ekuitas dalam perusahaan, umumnya diekspresikan sebagai debt-to-equity ratio / leverage (ato.gov.au, 2020). Thin capitalization mengindikasikan proporsi penggunaan hutang jangka panjang yang besar pada struktur keuangan perusahaan. OECD (2012) mendefinisikan thin capitalization sebagai kondisi dimana badan usaha dibiayai oleh tingkat utang yang lebih tinggi daripada modal yang ditanamkan di dalam badan usaha tersebut. Perusahaan dengan status ini disebut memiliki tingkat leverage atau gearing yang tinggi. Tingkat utang dalam pembiayaan suatu badan usaha mempengaruhi aspek perpajakannya 
melalui berbagai peraturan perpajakan yang mengijinkan pembebanan beban bunga dan utang bunga sebagai pengurang penghasilan kena pajak, sehingga secara efektif perusahaan dengan tingkat leverage yang tinggi memiliki beban pajak yang lebih rendah (Miller \& Modigliani, 1963).

Mekanisme ini dapat dimanfaatkan oleh perusahaan multinasional dengan cara memaksimalkan beban pajak di yurisdiksi tingkat pajak tinggi untuk meminimalkan beban pajak grup perusahaan secara keseluruhan. Berbagai penelitian lebih lanjut telah menemukan bukti pengaruh perbedaan tingkat pajak antar yurisdiksi berkorelasi dengan struktur keuangan perusahaan multinasional yang konsisten dengan minimalisasi beban pajak perusahaan (Desai et al.,2004; Huizinga et al., 2008). Berbagai penelitian yang mendukung adalah penelitian oleh Liu dan Cao (2007) pada konteks pasar modal Tiongkok selama periode 1998-2004 yang menemukan bahwa tingkat leverage berpengaruh signifikan yang negatif pada effective tax rate (ETR). Penelitian oleh Richardson dan Lanis (2007) pada konteks Australia juga menemukan pengaruh yang signifikan dari tingkat leverage terhadap effective tax rate (ETR) perusahaan. Berdasarkan literatur yang tersedia, penelitian ini mengembangkan hipotesis berikut: $\mathrm{H} 2$ : thin capitalization berpengaruh positif terhadap penghindaran pajak.

\section{METODE}

\section{Unit Analisis}

Penelitian ini menggunakan unit analisis perusahaan yang terdaftar di Bursa Efek Indonesia (BEI) selama periode 2017 hingga 2019. Penelitian ini tidak menggunakan perusahaan jasa finansial, perusahaan jasa asuransi karena menggunakan standar akuntansi yang berbeda secara signifikan yang memberikan hambatan dalam penelitian. Data yang digunakan dalam penelitian ini didapatkan dari laporan keuangan yang tersedia secara publik di halaman web BEI (idx.co.id).

\section{Variabel dependen}

Variabel dependen dalam penelitian ini adalah Effective Tax Rate (ETR). Semakin rendah nilai ETR maka dapat disimpulkan bahwa semakin tinggi tingkat tax avoidance yang dilakukan oleh sebuah perusahaan. Nilai ETR mengacu pada penelitian oleh Rego (2003), yang ditentukan dengan perhitungan:

$$
E T R=(\text { Income tax }) /(\text { Profit before income tax })
$$


Dimana:

$\mathrm{ETR}=$ Effective Tax Rate

Income tax = pajak penghasilan yang dibayarkan

Profit before income tax $=$ penghasilan sebelum pajak yang dilaporkan

\section{Variabel independen}

Variabel independen dalam penelitian ini adalah multinationality (MULTI), thin capitalization (THINCAP)

MULTI adalah variabel independen yang dihitung dari jumlah entitas anak di luar Indonesia dibagi dengan jumlah total entitas anak yang dimiliki perusahaan. Variabel MULTI akan bernilai " 0 " untuk perusahaan tanpa entitas anak di luar Indonesia dan bernilai " 0 " $<\mathrm{X} \leq$ "1" bagi perusahaan dengan entitas anak di luar Indonesia.

THINCAP adalah variabel independen dummy variable thin capitalisation perusahaan, bernilai "1" jika debt-to-equity ratio perusahaan melebihi 1,5 dan net interest expense melebihi $50 \%$ dari cash from operating activities, dan "0" jika sebaliknya, mengacu pada penelitian sebelumnya oleh Suqih dan Jasman (2018).

\section{Variabel kontrol}

INTANG adalah variabel independen intangible asset perusahaan, dihitung dengan cara membagi jumlah intangible asset dengan jumlah total aset, mengacu pada penelitian sebelumnya oleh Suqih dan Jasman (2018).

SIZE adalah variabel independen ukuran perusahaan, dihitung dengan logaritma natural dari total aset, mengacu pada penelitian sebelumnya oleh Hanlon (2005).

\section{Uji Hipotesis}

Analisis regresi linier berganda untuk menganalisis hubungan antar variabel adalah berikut:

$$
E T R=\alpha+\beta_{1}(M U L T I)+\beta_{2}(\text { THINCAP })+\beta_{3}(I N T A N G)+\beta_{4}(S I Z E)+e
$$

Keterangan:

$\begin{array}{ll}\text { ETR } & =\text { effective tax rate } \\ \text { MULTI } & =\text { multinationality } \\ \text { THINCAP } & =\text { thin capitalisation } \\ \text { INTANG } & =\text { intangible asset } \\ \text { SIZE } & =\text { size } \\ \text { e } & =\text { error term }\end{array}$




\section{HASIL}

\section{Obyek Penelitian}

Objek yang digunakan dalam penelitian ini adalah seluruh perusahaan kecuali sektor keuangan dan perbankan yang terdaftar di Bursa Efek Indonesia (BEI) pada tahun 2017-2019. Obyek perusahan yang akan digunakan sebagai data adalah yang memenuhi syarat sesuai dengan seluruh kriteria variabel penelitian. Bila terdapat perusahaan yang tidak memenuhi maka objek tersebut tidak digunakan dalam penelitian. Dari populasi yang ada tersebut kemudian diseleksi sesuai dengan kriteria-kriteria yang telah ditentukan. Berikut ini akan ditampilkan tabel 1 tentang kriteria pengambilan sampel untuk objek penelitian:

Tabel 1: Kriteria Pengambilan Sampel Penelitian

\begin{tabular}{|l|l|}
\hline Keterangan & Jumlah \\
\hline Badan usaha yang terdaftar di BEI selama periode 2017-2019 & 1786 \\
\hline Kriteria Pemilihan Sampel & $(297)$ \\
\hline Badan usaha jasa keuangan, perbankan, dan asuransi & $(457)$ \\
\hline $\begin{array}{l}\text { Badan usaha yang delisting atau suspended atau sempat tidak } \\
\text { mengeluarkan laporan tahunan selama periode 2017-2019 (termasuk } \\
\text { badan usaha yang menggunakan mata uang asing) }\end{array}$ & 1032 \\
\hline \begin{tabular}{l} 
Total sampel yang digunakan sebagai objek penelitian \\
\hline Jumlah outlier
\end{tabular} & $\mathbf{9 0 5}$ \\
\hline Jumlah data yang diuji & $127)$ \\
\hline
\end{tabular}

Sumber: data sekunder yang diolah, 2021

\section{Analisis Data}

Analisis data pada penelitian ini dilakukan dengan menggunakan software IBM SPSS Statistics 26.

Tabel 2: Uji ANOVA ( $F$-Test) pada Set Data

\begin{tabular}{lrrrrl}
\hline & $\begin{array}{c}\text { Sum of } \\
\text { Squares }\end{array}$ & df & $\begin{array}{c}\text { Mean } \\
\text { Square }\end{array}$ & F & Sig \\
\hline Regression & 0,593 & 4 & 0,148 & 3,277 & 0,011 \\
Residual & 40,678 & 900 & 0,045 & & \\
Total & 41,271 & 904 & & & \\
\hline
\end{tabular}


Pada set data gabungan semua perusahaan dalam uji ANOVA menghasilkan nilai signifikansi (Sig.) 0,011 yang menunjukkan bahwa model regresi yang digunakan telah sesuai dengan data penelitian.

Tabel 3: Uji Parsial (t-Test) pada Set Data

\begin{tabular}{lrrrrrr}
\hline & \multicolumn{2}{c}{$\begin{array}{c}\text { Unstandardized } \\
\text { Coefficients }\end{array}$} & \multicolumn{2}{c}{$\begin{array}{c}\text { Unstandardized } \\
\text { Coefficients }\end{array}$} & \multirow{2}{*}{ t } & sig \\
\cline { 2 - 3 } & $\mathrm{B}$ & Std. Error & & Beta & & \\
\hline Multinasionalitas & 0,091 & 0,045 & & $-0,067$ & $-2,033$ & 0,042 \\
Tingkat Leverage & 0,039 & 0,015 & & 0,087 & 2,627 & 0,009 \\
Aset tak berwujud & 0,000 & 0,004 & & 0,002 & 0,073 & 0,942 \\
Ukuran & 0,007 & 0,004 & & 0,056 & 1,685 & 0,092 \\
\hline
\end{tabular}

Berdasarkan hasil uji parsial (uji t) pada tabel 3, terlihat bahwa variabel independen, yaitu variabel multinasionalitas (MULTI) dan tingkat leverage (THINCAP) berpengaruh signifikan terhadap variabel dependen.

\section{PEMBAHASAN}

\section{Hipotesis 1}

Pada tabel 3 menunjukkan bahwa MULTI berpengaruh terhadap ETR, yang ditandai dengan nilai signifikansi variabel MULTI sebesar 0,042. Hal ini menunjukkan bahwa status multinasionalitas berpengaruh terhadap penghindaran pajak (ETR) Nilai unstandardized coefficients B bernilai -0,091 (negatif) menandakan pengaruh negatif multinasionalitas terhadap nilai effective tax rate (ETR). Semakin rendah nilai ETR menunjukkan semakin tinggi nilai penghindaran pajak. Dengan demikian maka hasil olah data menyimpulkan bahwa status multinasionalitas meningkatkan usaha-usaha penghindaran pajak (penghindaran pajak semakin tinggi) sehingga hipotesis 1 diterima/terbukti.

Hasil dari penelitian ini sejalan dengan hasil penelitian oleh Taylor \& Richardson (2013), penelitian oleh Hanlon, Mills, \& Slemrod (2007), dan penelitian oleh Suqih \& Jasman (2018) dimana ketiga penelitian sebelumnya mencapai kesimpulan bahwa perusahaan multinasional memiliki kemungkinan lebih besar untuk melaksanakan praktik tax avoidance. Operasional bisnis perusahaan multinasional tersebar di berbagai negara, yang mana selain ditujukan untuk meningkatkan scale economies, akses terhadap teknologi, juga memanfaatkan perbedaan biaya operasi (Porter, 1985) Pengembangan ke berbagai negara juga dipengaruhi oleh perjanjian antar negara yang saling menguntungkan, khususnya dalam bidang pajak. Perjanjian antar yurisdiksi dapat dimanfaatkan untuk tax avoidance oleh perusahaan 
multinasional melalui praktik treaty shopping yaitu pemilihan yurisdiksi sehingga tingkat pajak korporat yang dihasilkan menjadi menguntungkan untuk penghematan beban pajak yang ditanggung oleh grup perusahaan secara keseluruhan dapat diminimalkan (Yonah dan Panayi, 2010)

Selain pemanfaatan kerjasama bisnis, profit shifting juga merupakan adalah strategi penghindaran pajak yang dapat dipakai oleh perusahaan multinasional. Perusahaan mempunyai kemampuan untuk memindahkan penghasilan yang dapat dikenakan pajak dari suatu negara ke negara lain yang memiliki tingkat pajak lebih rendah (PWC, 2011). Profit shifting dapat dilakukan juga melalui manipulasi transfer pricing dengan cara menetapkan harga transfer serendah-rendahnya untuk barang ke perusahaan afiliasi di negara dengan tingkat pajak tinggi dan sebaliknya menetapkan harga transfer setinggi-tingginya untuk barang dari perusahaan afiliasi di negara dengan pajak rendah.

Kesimpulan multinasionalitas perusahaan berpengaruh terhadap penghindaran pajak menunjukkan bahwa perusahaan multinasional terbukti memanfaatkan berbagai keunggulannya untuk melakukan penghindaran pajak. Dengan demikian, pemerintah wajib lebih memperhatikan aktivitas perusahaan multinasional untuk mencegah tax avoidance agar pemasukan negara dapat dioptimalkan. Selain terhadap aktivitas perusahaan, pemerintah juga mungkin perlu mengkaji ulang beberapa peraturan guna memperkecil celah pemanfaatanya untuk mengurangi pembayaran pajak.

\section{Hipotesis 2}

Pengaruh THINCAP terhadap ETR ditandai oleh nilai signifikansi variabel sebesar 0,040 yang menunjukkan bahwa THINCAP berpengaruh terhadap penghindaran pajak (ETR) Nilai unstandardized coefficients B bernilai 0,040 (positif) pada set data perusahaan secara keseluruhan. Hal ini menandakan bahwa tingkat leverage perusahaan dinyatakan berpengaruh positif terhadap penghindaran pajak. Dengan kata lain disimpulkan bahwa penggunaan utang yang besar (THINCAP) pada perusahaan di Indonesia semakin meningkatkan pembayaran pajak. Sehingga hipotesis 2 ditolak/tidak terbukti. Berdasarkan kesimpulan tersebut maka fenomena yang selama ini bahwa perusahaan memanfaatkan beban biaya bunga yang merupakan deductible expense dalam menghindari pajak menjadi tidak terbukti.

Nilai leverage yang tinggi belum dapat dipastikan meningkatkan usaha penghindaran pajak selama perusahaan belum mengalami kesulitan keuangan atas utang yang dimilikinya. Berdasarkan penelitian Meilia dan Adnan (2017), serta Muttaqin \& Husen (2020) 
membuktikan bahwa penghindaran pajak dipengaruhi oleh perusahaan yang berada dalam kondisi financial distress. Perusahaan yang mengalami financial distress menjadi lebih agresif dalam melakukan penghindaran pajak karena kebutuhan untuk mengumpulkan uang tunai menjadi penting, terutama karena beban pajak adalah arus kas keluar yang signifikan bahkan untuk perusahaan tertekan dan meskipun ada efek reputasi negatif (Richardson, G. et al,. 2015 \& Sadjiarto, A. et al,. 2020)

Hasil kesimpulan tentang komposisi hutang terhadap penghindaran pajak yang negatif (semakin besar hutang semakin kecil penghindaran pajak) menunjukkan bahwa penetapan kebijakan utang di Indonesia dibandingkan dengan negara lain telah cukup efektif sehingga tidak dapat/kecil kemungkinannya untuk dipakai sebagai usaha penghindaran pajak. Dengan demikian maka fokus pemerintah dapat lebih difokuskan terhadap kebijakan yang lain.

\section{KESIMPULAN}

Berdasarkan hasil pengujian atas model regresi yang telah dilakukan, penelitian ini mencapai kesimpulan berikut:

1. Tingkat multinasionalitas (MNC) suatu perusahaan berpengaruh positif terhadap penghindaran pajak. Perusahan yang memiliki status multinasional terbukti melakukan penghindaran pajak

2. Tingkat leverage (THINCAP) suatu perusahaan berpengaruh negatif terhadap penghindaran pajak. Perusahan dengan tingkat pinjaman/utang tinggi terbukti

\section{DAFTAR PUSTAKA}

Aggarwal, R., \& Kyaw, N. A. (2008). Internal capital networks as a source of MNC competitive advantage: Evidence from foreign subsidiary capital structure decisions. Research in International Business and Finance, 22(3), 409-439.

Base erosion and profit shifting - OECD BEPS. (2017). Retrieved 5 January 2021, from https://www.oecd.org/tax/beps/

Booth, L., Aivazian, V., Demirguc-Kunt, A., \& Maksimovic, V. (2001). Capital structures in developing countries. The journal of finance, 56(1), 87-130.

Chatterjee, Samprit; Simonoff, Jeffrey (2013). Handbook of Regression Analysis. John Wiley \& Sons

Cristea AD, Nguyen DX (2016). Transfer pricing by multinational firms: New evidence from foreign firm ownerships. American Economic Journal: Economic Policy 8(3):170-202

Clausing KA (2015). The effect of profit shifting on the corporate tax base in the United States and beyond. Available at SSRN 2685442 
Cochrane, D.; Orcutt, G. H. (1949). "Application of Least Squares Regression to Relationships Containing Auto-Correlated Error Terms". Journal of the American Statistical Association.

Dahlan, A. (2018). Treaty Shopping, Sebuah Upaya Penghindaran Pajak yang Patut Diwaspadai | Direktorat Jenderal Pajak. From https://www.pajak.go.id/artikel/treatyshopping-sebuah-upaya-penghindaran-pajak-yang-patut-diwaspadai

Dharmapala, D. (2014). What do we know about base erosion and profit shifting? A review of the empirical literature. Fiscal Studies, 35(4), 421-448.

Dharmasaputra, M. (2014). Key Witness: An Investigation of Indonesia's Largest Ever Tax Scandal. Indonesia: PT Tempo Inti Merdeka Harian, Jakarta

Desai, M. A., Foley, C. F., \& Hines Jr, J. R. (2004). A multinational perspective on capital structure choice and internal capital markets. The Journal of finance, 59(6), 2451-2487.

Fuest, C., Spengel, C., Finke, K., Heckemeyer, J., \& Nusser, H. (2013). Profit shifting and aggressive tax planning by multinational firms: Issues and options for reform. ZEWCentre for European Economic Research Discussion Paper, (13-078).

Group, M. (2020). Understanding the Arm's Length Principles and the Consequences in Transfer Pricing. Retrieved 13 January 2021, from https://mucglobal.com/en/news/2271/understanding-the-arms-length-principles-andthe-consequences-in-transfer-pricing

Hejase A, Hejase H (2013). Research Methods: A Practical Approach for Business Students (2nd edition). Philadelphia, PA, USA: Masadir Inc

Howard V. Perlmutter, "The Tortuous Evolution of the Multinational Corporation," Columbia Journal of World Business, 1969, pp. 9-18.

Huizinga, H., \& Laeven, L. (2008). International profit shifting within multinationals: A multicountry perspective. Journal of Public Economics, 92(5-6), 1164-1182.

Ištok, M., \& Kanderová, M. (2019). Debt/asset ratio as evidence of profit-shifting behaviour in the Slovak Republic. Technological and Economic Development of Economy, 25(6), 1293-1308.

Kieso, D. E., Weygandt, J. J., \& Warfield, T. D. (2020). Intermediate accounting IFRS. John Wiley \& Sons.

Kim, K. A., \& Limpaphayom, P. (1998). Taxes and firm size in Pacific-Basin emerging economies. Journal of international accounting, auditing and taxation, 7(1), 47-68.

Klassen, K. J., \& Laplante, S. K. (2012). Are US multinational corporations becoming more aggressive income shifters?. Journal of Accounting Research, 50(5), 1245-1285.

Komunikasi, B. (2020). Kemenkeu Learning Center. Klc.kemenkeu.go.id. Retrieved 27 October 2020, from https://klc.kemenkeu.go.id/base-erosion-and-profit-shifting-beps/.

Lanis, R., \& Richardson, G. (2013). Corporate social responsibility and tax aggressiveness: a test of legitimacy theory. Accounting, Auditing \& Accountability Journal.

Maharani, I. G. A. C., \& Suardana, K. A. (2014). Pengaruh Corporate Governance, Profitabilitas, dan Karakteristik Eksekutif pada Tax Avoidance Perusahaan Manufaktur. E-jurnal Akuntansi, 9(2), 525-539. 
Model Tax Convention on Income and on Capital - Condensed Version (July 2010) - OECD. (2010). Retrieved 6 January 2021, from https://www.oecd.org/ctp/treaties/modeltaxconventiononincomeandoncapitalcondensedversionjuly2010.htm

Modigliani, F., \& Miller, M. H. (1963). Corporate income taxes and the cost of capital: a correction. The American economic review, 53(3), 433-443.

Noor, R.M.; N.S.M. Fadzillah; and N. Mastuki. 2010. "Corporate Tax Planning: A Study onCorporate Effective Tax Rates of Malaysian Listed Companies. ” International Journal of Trade, Economics and Finance 1, no. 2: 189-193.

Organisation for Economic Co-operation and Development (OECD) (2010). Transfer Pricing Guidelines for Multinational Enterprises and Tax Administration 2010, para.0.18. Paris: OECD Publishing.

OECD. (2013). Public Consultation: Draft Handbook On Transfer Pricing Risk Assessment. Paris: OECD Publishing

OECD. (2013). Public Consultation White Paper On Transfer pricing Documentation. Paris: OECD Publishing

OECD. (2012). Dealing Effectively with the Challenges of Transfer pricing, Paris: OECD Publishing

Omer, T.C.; K. Molloy; and D. Ziebart. 1993. "An Investigation of the Firm Size-Effective Tax Rate Relation in the 1980s." Journal of Accounting, Auditing and Finance 8, no. 2: 167182.

Ortax.org. 2021. Base Erosion and Profit Shifting, apa pengaruhnya bagi Indonesia? | Ortax your center of excellence in taxation. [online] Available at: $<$ https://www.ortax.org/ortax/?mod=issue\&page=show\&id=61\&list=\&q=\&hlm=4> [Accessed 28 December 2020].

Pohan, C. A. (2016). Manajemen Perpajakan Strategi Perencanaan Pajak dan Bisnis Edisi Revisi. Jakarta: PT Gramedia Jakarta.

Porter, Michael E. 1986. Changing patterns of international competition. California Management Review, 28: 9-40.

PwC (2011). Transfer Pricing and Developing Countries - Final Report. EuropeAid Implementing the Tax and Development policy agenda

Readhead, A. (2016). Transfer pricing in the mining sector in Zambia. Case Study.

Rego, S. O. (2003). Tax-avoidance activities of US multinational corporations. Contemporary Accounting Research, 20(4), 805-833.

Richardson, G., Taylor, G., \& Lanis, R. (2013). Determinants of transfer pricing aggressiveness: Empirical evidence from Australian firms. Journal of Contemporary Accounting \& Economics, 9(2), 136-150.

Riyanto, Bambang. 2013. Dasar-dasar Pembelanjaan Perusahaan. Yogyakarta: BPFE

Root, F. R. (1994). Entry strategies for international markets. Jossey-Bass

Root, F. R., \& Kramer, R. L. (1973). International trade \& investment: theory, policy, enterprise (Vol. 77). South-Western Pub. Co. 
Sembiring, E. R. (2005). Karakteristik Perusahaan dan Pengungkapan Tanggung Jawab Sosial. Studi Empiris pada Perusahaan yang terdaftar di Bursa Efek Jakarta. Simposium Nasional Akuntansi VIII. Solo.

Sugianto, D., 2019. Adaro Dituduh Hindari Pajak, DJP: Kita Pelajari. [online] detikfinance. Available at: <https://finance.detik.com/bursa-dan-valas/d-4612405/adaro-dituduhhindari-pajak-djp-kita-pelajari?_ga=2.45839652.1219792938.161077516990508083.1601439597> [Accessed 19 December 2020].

Suqih, L. R., \& Jasman, J. (2018). Profit Shifting Determinants And Tax Haven Utilization: Evidence From Indonesia. Russian Journal of Agricultural and Socio-Economic Sciences, 83(11).

Taylor, G., Richardson, G., \& Lanis, R. (2015). Multinationality, tax havens, intangible assets, and transfer pricing aggressiveness: An empirical analysis. Journal of International Accounting Research, 14(1), 25-57.

Tax Haven Definition from Financial Times Lexicon. Web.archive.org. (2020). Retrieved 8 November 2020

"Tax haven definition and meaning | Collins English Dictionary". Collins Dictionary. Archived from the original on 28 December 2017. Retrieved 27 December 2017. A tax haven is a country or place which has a low rate of tax so that people choose to live there or register companies there in order to avoid paying higher tax in their own countries." (2)

Thin capitalisation. (2020). Retrieved 4 February 2021, from https://www.ato.gov.au/Business/Thin-capitalisation/

Twesige, D., \& Gasheja, F. (2019). Determinants of profit shifting by multinational companies in developing countries: A case of Rwanda. Journal of Accounting and Taxation, 11(4), 67-78.

Twesige, D., Gasheja, F., Barayendema, J., \& Uwamahoro, A. (2020). Effect of Transfer Pricing on Profit Shifting by Multinational Companies in Developing Countries: A Case of Rwanda. In Rwandan Economy at the Crossroads of Development (pp. 149-167). Springer, Singapore.

Wolf, M. (2004). Globalisation and interdependence. Address to UN Outubro.

Wolf, M. (2004). Why globalization works (No. 3). Yale University Press.

Widowati, A. I. (2011). Faktor-Faktor yang Mempengaruhi Pelaporan Aset Tak Berwujud Pada Perusahaan yang terdaftar di BEI. Paper disajikan pada Seminar Nasional Update Ekonomi, Akuntansi dan Bisnis Indonesia. 